\title{
INTEGRATED SCHOOL MANAGEMENT-CHARACTER EDUCATION AFFIRMATION: A CASE STUDY IN MUHAMMADIYAH WIROBRAJAN 3 ELEMENTARY SCHOOL YOGYAKARTA
}

\author{
Atika $^{1}$, Zainal Arifin ${ }^{2}$, Nora Saiva Jannana ${ }^{3}$ \\ ${ }^{1}$ Islamic Educational Management Department, Universitas Islam Negeri Sulthan Thaha \\ Saifuddin Jambi, Indonesia \\ 2,3Islamic Educational Management Department, Universitas Islam Negeri Sunan Kalijaga, \\ Yogyakarta, Indonesia \\ Email: atika@uinjambi.ac.id ${ }^{1}$, zainal.arifin@uin-suka.ac.id ${ }^{2}$, nora.jannana@uin-suka.ac.id ${ }^{3}$
}

\begin{tabular}{l|l|l} 
Received: February 2021 & Accepted: July 2021 & Published: August 2021
\end{tabular}

\begin{abstract}
:
This study aims to describe the integrated school management with PPK. The research was conducted at Muhammadiyah Wirobrajan 3 Elementary School in Yogyakarta City (Wibraga). This research is a qualitative approach. Data were collected through interviews, observations, and documentation. The results of this research are as follows: Firstly, the school management was integrated with the character education program at Wibraga, covering four functions; 1 ) The systemic-integrative planning by forming a development team for formulating PPK programs; 2) The organizing job description with three departments, the head of Curriculum and Teaching, ISMUBA and BHI, and Activities and Student Affairs; 3) The implementation of PPK programs was integrated through intra-curricular activities, the class based on co-curricular and extracurricular activities, Islamic and society life culture; 4) The controlling of PPK programs was realized in attitude books, school regulations, and external supervision with teachers, public relations, student parents, and local society.
\end{abstract}

Keywords: Management, Character Education Affirmation, Excellent Academic

\begin{abstract}
Abstrak:
Penelitian ini bertujuan untuk mendeskripsikan manajemen sekolah yang terintegrasi dengan program PPK. Penelitian dilakukan di SD Muhammadiyah Wirobrajan 3 Kota Yogyakarta (Wibraga) dengan pendekatan deskriptif kualitatif. Data dikumpulkan melalui wawancara, observasi, dan dokumentasi. Hasil penelitian menjelaskan manajemen sekolah terintegrasi dengan program PPK di SD Muhammadiyah Wibraga meliputi empat fungsi, yaitu; 1) perencanaan yang sistemik-integratif dengan membentuk tim pengembang PPK yang bertugas merumuskan program-program PPK; 2) pengorganisasian dengan pembagian kerja kepada tiga kepala bidang (Kabid), yaitu: Kabid. Kurikulum dan Pengajaran mengkoordinir kegiatan PPK berbasis kelas, Kabid Ismuba dan BHI mengkoordinir kegiatan PPK berbasis budaya sekolah dan masyarakat bekerja sama dengan Kabid Kegiatan dan Kesiswaan; 3) pelaksanaan program PPK terintegrasi dengan kegiatan intrakurikuler, kokurikuler dan ekstrakurikuler berbasis kelas, budaya hidup Islami dan masyarakat; dan 4) pengawasan program PPK menggunakan buku attitude, peraturan sekolah, dan pengawasan eksternal dengan melibatkan guru, humas, orangtua, dan masyarakat.
\end{abstract}

Kata Kunci: Manajemen, Penguatan Pendidikan Karakter, Akademik Luar Biasa 


\section{INTRODUCTION}

The government's policy on character education in educational institutions since 2010 has not shown satisfactory results. Educational institutions in Indonesia still can only produce graduates (outcomes) with an adequate level of intellectuality but lack of morality (Arif \& Pratama, 2019; Maryam, 2018). They do not have good personalities and contract social diseases, such as moral damage, morality, and ethics (Lickona, 2013). Education aims to realize a human character, noble, and human (Almuhajir, 2021).

The fact of the field found a high deviation of the character of the nation's generation. For example, Yogyakarta became the number two province with the highest category of drug users after Jakarta (Indonesian National Narcotics Agency, 2016). In 2015, the National Family Planning Health Agency (BKKBN) Yogyakarta also recorded 1,078 junior and high school students carrying out teenage labor and extramarital pregnancies (Health Profile Data of Yogyakarta Special Region, 2016). Cases of bullying, physical fights and attacks, and klitih also color the behavior of Yogyakarta teenagers.

Character education is a system of applying moral values to students through science, awareness, or will to form akhlakul karimah (Wulandari \& Kristiawan, 2017). Character education to educate an ethical, responsible, and caring generation. The process involves moral knowing, moral feeling, and moral action (Savitri, 2015). Character education in schools can create an environment that helps students develop character (Berkowitz \& Bier, 2005).

Character Education Strengthening Program (PPK) is regulated in Presidential Regulation No. 87 of 2017 Article 3 by applying Pancasila values, namely religious, honest, tolerant, disciplined, hard work, creative, independent, democracy, curiosity, national spirit, love of homeland, respect for achievements, communicative, peace-loving, reading, environmental care, social care, and responsibility.

Character is a personality formed from the internalization of various virtues (values, morals, norms) that are believed to be the basis in behaving (Kemindikbud, 2010). Character education functions for; 1) the formation and development of potential in behaving, 2) improvement and strengthening through the role of families, schools, communities, and governments, 3) other cultural filters that are incompatible with the character of the nation.

Character education has three main functions: first, the formation and development of potential. Character education shapes and develops students' potential to think well, be kind, and behave according to the philosophy of Pancasila. Second, the repair and strengthening functions. Character education improves and strengthens the role of families, academic units, communities, and governments to participate and be responsible in developing the potential of citizens and nation-building towards a developed, independent, and prosperous nation. The third, the filter function. Character education sorts out the culture of the government itself. It filters the culture of other countries that are incompatible with the nation's cultural values and the character of a dignified nation. 
In his research, Maisaro et al., (2018) explained that character education strengthening programs are managed by implementing planning management, organizing, implementation, supervision, and evaluation of programs. Planning is carried out in several stages, namely observation, coordination meetings, preparing work programs. Organizing was formed to achieve the objectives effectively and efficiently, with the principal as the supreme power holder, assisted by a team of developers and school coordinators. The program's implementation through four stages of activities is integrated, cultivating, civility, and cooperation with parents of students. The process of monitoring the PPK program is direct and evaluated with four stages, namely the preparation of evaluation plans, supervising processing data, and meeting improvements. The management of the PPK program at SD Negeri Bunulrejo 2 Malang through the management function went well.

Qoyyimah (2016) findings show that character education policies are allowed to be included in various types of morality to be transmitted into ELF (English a Foreign Language) classes. Secular and religious morality is evident in schools in Indonesia. It is derived from the parallels between character education and ELF subjects. The transmission of secular morality is found in the teacher's learning plan and is observed in the classroom as learning from pedagogy in an implied and written manner. Religious character is echoed by school residents, with teachers as the top priority in carrying out these activities. The local religion strongly influences the personality of the learners. ELF learning seeks to offer solutions to moral challenges in highly religious societies through strengthening character education.

A character education strengthening program is an educational policy made to overcome student character as a curriculum booster in 2013. Strengthening character education as a pivot of education alongside intellectuality is essential to overcome the various moral crises that color the younger generation's lives. The multidimensional crisis engulfing Indonesia today stems from the weak development of nation and character building. The application of the 2013 curriculum demands character education in schools. The PPK program is essential to support the management of various moral crises of the younger generation and the country sourced from the weak nation and character-building (Rosyad \& Zuchdi, 2018). This article focuses on the management of PPK Program implemented in PPK Piloting School. PPK program that is managed well in accordance with the management function is expected to improve the effectiveness of the implementation of PPK programs in schools and have a positive impact on the quality of graduates and the character values of learners through planting (inculcation) and habituation (habituation).

\section{RESEARCH METHODS}

This research method uses descriptive qualitative that generates data in words or descriptive (Sugiyono, 2013). This study describes the PPK program at SD Muhammadiyah Wirobrajan 3 as a PPK piloting school and analyses school management that integrates with PPK. 
This research was conducted at SD Muhammadiyah Wirobrajan 3 (Wibraga), one of the schools that piloted PPK program in Yogyakarta. The research subjects consisted of the principal, the head of ISMUBA and BHI, the director of student affairs and activities, and the head of curriculum and teaching as the formulation team of the PPK program. The data collection method uses observation, interview, documentation, and triangulation as field data validation (Moleong, 2007).

\section{RESULTS AND DISCUSSION PPK Program Policy}

The policy is to take care of the problem or the public interest, or government administration (Hasbullah, 2015). The term policy is different from wisdom. PPK policy has become a national movement in schools since 2010. However, character education practices in schools are still not adequate. PPK program becomes state policy because it relates to the public interest, namely the nation's character. It has been stipulated in Presidential Regulation No. 87 of 2017 and became part of the National Movement for Mental Revolution (GNRM) and Nawacita.

The PPK movement places character education as the core of national education in primary and secondary education (Kemendikbud, 2016). PPK policy aims to strengthen the internalization of Pancasila values, so as to develop a generation of Pancasilaists who are proud of their nation and country (Kemendikbud, 2011).

In summary, the objectives of PPK according to Presidential Regulation No. 87 of 2017 article 2 are; 1) equip students with Pancasila and character education, 2) character education as the core of national education through formal, nonformal, and informal channels, and 3) strengthen the competence of educators, educational personnel, learners, communities, and families.

\section{Establishment of SD Muhammadiyah Wirobrajan 3 as Piloting PPK}

The PPK movement is essential because many issues afflict the Indonesian nation, such as intolerance, religious violence, separatists, sexual crimes, student brawls, free association, and drugs. The school became a strategic place for the formation of the nation's character (Kemendibud, 2017). School plays an essential role in character education because students spend a lot of time studying at school (Zamroni, 2020).

The success of the PPK program cannot be separated from the school culture. The character strengthening model through school culture development is done by determining values, drafting, implementing, evaluating results, and redesigning cultural development. School culture development can be done by applying democratic values, cooperation, professionalism, a conducive academic climate, and cultural diversity (Subiyantoro, 2013).

Implementation of the PPK program at SD Muhammadiyah Wibraga aims to develop Islamic living culture through planting and habituation. For example, cultural habituation of $5 S$ (smiles, greetings, greetings, manners, manners), morning Quran, flag ceremony, antic activities, reflection activities, 
worship, wibraga market day, extracurricular, and character posters displayed in school.

The establishment of SD Muhammadiyah Wibraga has a religious character base because it is under the coordination of Muhammadiyah. So that the implementation of PPK in SD Muhammadiyah Wibraga is based on the vision of the school, namely: "The realization of the Islamic generation, noble character, patterned clean living, healthy, and cultured environment." This vision is realized through the process of habituation and inculcation.

A clean and healthy lifestyle is realized by infrastructure arrangement, so the school was named a healthy school or Hygienic canteen in 2010. This school is also the best II as a school of environmental care and sophisticated atmosphere in 2011.

SD Muhammadiyah Wibraga as the piloting of PPK in Yogyakarta city is the government's appreciation of the character programs. It has been run such as adiwiyata, healthy schools / hygienic canteens, school order Patroli Ketertiban Sekolah (PKS), Dokter Cilik, Pustakawan Cilik, and Pengajian Tunas Mentari (Cahyono, 2019).

The implementation of character education at SD Muhammadiyah Wibraga became a priority. SD Muhammadiyah Wibraga is included in the top 5 best in Indonesia in the character education competition. One of the competitions is Polisi Cilik (Polcil) in 2017, which received the best national title (Widiana, 2019).

The basis of PPK planning refers to; 1) government rules (Perpres No. 87 of 2017), 2) field observations based on school conditions, and 3) records the ethics, interests, and talents of students (Maisaro, Wiyono, \& Arifin, 2018). SD Muhammadiyah Wibraga is piloting PPK because of the conducive learning environment (Widiana, 2019).

\section{Management of PPK Program at SD Muhammadiyah Wirobrajan 3}

\section{PPK Program Planning}

Planning is a target decision-making activity that will be achieved, actions to be taken, and appointing the executor of its duties (Silviani et al., 2021). Education planning management is the science of managing educational resources to realize the atmosphere of learning and learning so that students actively develop potential.

There are two planning functions, namely; 1) the preparation of a series of activities that will be carried out to achieve the objectives taking into account existing resources, and 2) using limited resources effectively to achieve the goals (Wiyani, 2012).

Planning of the PPK program at SD Muhammadiyah Wibraga began by forming a PPK development team from the school's organizational structure for easy coordination. PPK planning through the formulation of objectives, direction of character education activities and improvement of programs by identifying and analyzing the content of character values in intracurricular and extracurricular activities (Widiana, 2019). The PPK plan is then disseminated by teachers, committees, students, and parents/guardians. 
The coordinator of PPK program at SD Muhammadiyah Wibraga under three Heads of Field (Kabid), namely; 1) Kabid. Curriculum and Teaching sector coordinates PPK on classroom learning in RPP and Syllabus, 2) Kabid. The Field of Activities and Student Affairs corresponds PPK on extracurricular activities, 3) Kabid. ISMUBA and BHI coordinate PPK on alIslam and Kemuhammadiyahan and Islamic culture.

SD Muhammadiyah Wibraga also designed an integrative curriculum developed from the core values of the Kemuhammadiyahan curriculum and the national curriculum at the SD/MI level. PPK planning is based on the school's discipleship, vision, and mission and is then disseminated to students and parents/guardians (Cahyono, 2019). Socialization through various media during the orientation of students (Taufiq, 2019).

\section{PPK Program Organizing}

Organizing is organizing and sharing work with group of people and is given responsibility and authority. The organization of the PPK program at SD Muhammadiyah Wibraga is adapted to the school's organizational structure. The principal holds the highest power then assisted by the development team of PPK (the Kabid).

The principal set various PPK programs and formed a division of work to three districts, namely the Head of Curriculum and Teaching coordinating class-based PPK activities, Kabid. Ismuba and BHI coordinate PPK activities based on school and community culture in collaboration with the Head of Activities and Student Communities.

Character building is done by forming an internal organizational structure of the school, but it needs synchronization between family, environment, and social friends. Principals and teachers build positive interactions and communication with parents/guardians to monitor the development of student's character through child-friendly committees. (Widiana, 2019).

\section{PPK Program Implementation}

Implementation is a management function related to the arrangement and division of effective and efficient work to achieve organizational goals (Kontz \& O'Donnel, 1990). Implementing the PPK program at SD Muhammadiyah Wibraga uses the approach of civility, habituation, and strengthening character values in daily life in the classroom (school) and home with the role model of class teachers and parents.

The PPK program at SD Muhammadiyah Wibraga adjusts the class level, time, and place conducted in synergy between formal activities in the classroom, extracurricular activities, and Islamic living culture.

The basis for implementing the PPK program at SD Muhammadiyah Wibraga includes: First, class-based PPK program, integrated into subjects (syllabus and RPP), self-development, and school culture (Astasari, 2019). The application and development of character values are implemented in all school subjects (Taufiq, 2019). 
The implementation of PPK is also integrated with self-development activities through (1) routine activities such as ceremonies, hygiene checks, praying in learning activities, and (2) spontaneous activities, such as waste disposal culture, polite behavior, and (3) civility activities exemplified by teachers and educational personnel 4) conditioning activities, such as clean toilets, trash cans, neat schools and regular learning equipment, and others (Kurniawan, 2018).

The PPK program at SD Muhammadiyah Wibraga emphasizes five characters: religious, nationalist, independent, mutual assistance, and integrity. Spiritual nature is applied through the Islamic living culture program. The nationalist feeling is implemented at the flag ceremony every Monday morning. Independent character and gotong-royong are involved through cooperative learning in the classroom, and integrity is used in extracurricular activities (Cahyono, 2019).

Classroom management, methods (strategies), and learning evaluation models also strengthen character education in schools. Teachers need to create the right approach and interesting learning situations to be active and highly motivated to learn (Wahid et al., 2018; Zulfaizah, 2018)

The ideal learning method in character education is student active learning. The learning experience is built through intervention and habituation to achieve the goal of strengthening character. Here it is necessary to play an active role of the teacher to emphasize character values during learning and teaching activities.

Character value intervention in learning is not enough to provide examples of good behavior. Still, a comprehensive method is needed covering all dimensions of self-processing, namely thinking, exercise, and sports. Habituation is related to self-habituation, which includes situations, conditions, and reinforcements created so that students can behave according to the values of character that have been internalized and personalized through the intervention process (Darmayanti \& Wibowo, 2014).

Schools as small communities can integrate subjects with daily (contextual) life. Learners can be active, and teachers guide and direct. The role of teachers in the classroom is as advisors, advisers, guides, and creators of a cooperative and democratic learning environment so that students can develop potential (Subiyantoro, 2013).

Second, PPK Program is based on Islamic Living Culture. School culture is the atmosphere of school life in interacting between students and teachers. This internal interaction is tied to various rules, norms, morals, and ethics that apply in schools.

The development of school culture is carried out through selfdevelopment activities, such as routine activities, spontaneous, conscientiousness, and conditioning. Activities are carried out with a good approach of civility, habituation, personification, and role models. Examples; 1) routine activities: flag ceremony, handshake, greetings, greeting smiles, morning Quran, congregational prayers, and small 
philanthropy, 2) spontaneous activities: antlik, visiting friends/teachers affected by disasters, collecting donations, teachers reprimanding students who throw garbage carelessly, thank you when getting help, teachers invite students to clean the classroom.

The positive culture shown is the culture of shaking hands and the morning Quran. Every morning, teachers line up neatly to welcome students to school. Students spontaneously shake hands by kissing the teacher's hand and then say hello.

Character education has an essential role in the effort to realize Islamic (religious) culture. However, often the cultural impact of globalization affects the character of learners. The culture of globalization can hinder the internalization of PPK and students are less aware of the importance of religious character values (Islamic), even reject them.

The integrity of character education values at SD Muhammadiyah Wibraga is reflected in Islamic living culture programs. Creating a religious atmosphere is an effort to condition the school's atmosphere with religious values and behaviors. The process of educating learners to become human beings of faith and piety to God and noble character is not only enough to rely on 2 hours of religious subjects (Muhaimin, 2012), but it needs to be continuously fostered in the classroom and outside the school. This development requires cooperation between school residents (Taufiq, 2019).

SD Muhammadiyah Wibraga also used environmental concerns to be beautiful and comfortable to learn. Enforcement of school rules aims to foster morals, self-control in attitudes, and respect for anyone. SD Muhammadiyah Wibraga carries the paradigm of Muhammadiyah as a charitable movement to create an actual Human or Islamic society.

The PPK program at SD Muhammadiyah Wibraga combines five pillars of character that become the noble ideals of Muhammadiyah school, namely; 1 ) the character of the love of the homeland is instilled through Hizbul Wathon and flag ceremony every Monday morning (Widiana, 2019), 2) strong determination and physical through the martial arts of The Sacred Site (Cahyono, 2019), 3) discipline and nationalism through the Cilik Police program in collaboration with the Ditlantas Polda DIY (Widiana, 2019).

School culture is very influential on the achievements and behavior of students. School culture can be done through habituation of values in daily life, adult transparency, ecosystem, co-curricular, extracurricular, management, and considering school norms, regulations and traditions (Kemendikbud, 2011).

Third, Community Based PPK Program. In PPK implementation, the community has a role and responsibility to create a comfortable and supportive atmosphere (Kurniawan, 2018). Community-based PPK program can be through; 1) environmental potential as a learning resource such as art activists, community leaders, businesses and industry, 2) synergy with academic programs, education activists, and NGOs, 3) cooperation with local governments, communities, and parents/guardians (Kemindukbud, 2017). 
The community-based PPK program at SD Muhammadiyah Wibraga cooperates with the DIY Police in coaching polcil character groups (Little Police). This program is one of the innovations as a cultured school of orderly traffic and obeys the rules in driving. In fact, in June 2017, polcil team of SD Muhammadiyah Wibraga managed to represent DIY at the national level and get the best predicate.

Other community-based PPK programs at SD Muhammadiyah Wibraga are Sunday Morning Study/ Pengajian Orang Tua (POT Wibraga) and Pengajian Tunas Mentari. POT Wibraga is exclusively for parents /guardians and the surrounding community, while Tunas Mentari is for students and the community. Technically, this activity is organized by parents/guardians so that the action can be carried out in the house of one of the students or the mosque around the student's residence. Activities coordinated by students are the assignment of hosts, reading the holy Quran, and speakers (Cahyono, 2019).

Habituation in the PPK program Islamic perspective is called takhalluq, in line with the word akhlak. Takhalluq is to push yourself and get used to doing things over and over again. Prophet Muhammad (PBUH) said knowledge is obtained by learning (forcing yourself and repeating wisdom). Chest space through habituation expands the chest. Whoever seeks good will be granted, and whoever seeks to avoid evil will be avoided (Narrated by al-Khatib). Deeds that have become habitual will be easy to do, without much thought, and become moral. Takhalluq needs encouragement from the outside because it initially feels heavy. A form of motivation is knowledge gained from the conscientiousness of admired figures (Shihab, 2016).

In line with the concept of Takhalluq, Imam Al-Ghazali has a method of the moral formation called riyadhah, which is a psychiatric exercise through an effort to get used to not doing things that pollute the soul. Habituation is regularly done to fully train in refraining from sin and sin (Nasution \& Siregar, 2013).

The habituation method in PPK is also applied in SD Muhammadiyah Wibraga. Students are expected to make good habits full of passion and awareness. For example, sort the trash by type and throw it in place. Educating elementary school children is more complex than teenagers (junior high school) because elementary school children tend to easily forget obligations or good habits in school (Cahyono, 2019). Other habituation such as neatly arranging shoes, queuing culture when buying food (Afriyadi, 2019).

Strategic programs in PPK have been summarized in the curriculum, both national, Muhammadiyah, and the typical curriculum of SD Muhammadiyah Wibraga. PPK program is also supported by adequate infrastructures such as mosques and halls and extracurricular activities to develop social responsibility and students' potential (achievements). Religious morality is a top priority in this activity. The results of this study 
showed that the personality of learners is strongly influenced by local religion.

\section{PPK Program Supervision}

The supervisory function is a series of activities to analyze, interpret the process, and obtain the results of the PPK program at SD Muhammadiyah so that it becomes meaningful information in policymaking to determine the success rate of the PPK program and future improvement plans.

Supervision of PPK program conducted by SD Muhammadiyah Wibraga using attitude book, school regulations, and external supervision by involving homeroom and public relations to observe students' behavior while in school and home through activity books.

The supervision process at SD Muhammadiyah Wibraga is conducted periodically by; 1) developing indicators of agreed values, 2) compiling assessment instruments, 3) recording indicators, 4) analyzing and evaluating teachers, and 5) follow-up. This supervision is carried out on the activities of students while in school (Cahyono, 2019).

Supervision is carried out by monitoring the activities of students, such as regular study and Tunas Mentari involving parents/guardians. The aim is to facilitate teachers and parents of mutual communication (coordination) for the success of PPK. Supervision is also carried out on intracurricular activities in the classroom and extracurricular (Cahyono, 2019).

In general, the monitoring process at SD Muhammadiyah wibraga includes; 1) the implementation of the PPK program periodically and continuity, 2) the attitudes and behaviors of learners in habituation, 3) the attitudes and behaviors of learners to see the constraints of the implementation of the PPK program and identification of existing problems, 4) analyzing data found in the field to prepare recommendations related to the improvement of the PPK program, 5) measuring the success rate of the PPK program, and 6) the involvement of parents/guardians through the study of Tunas Mentari to monitor the development of attitudes and behaviors of students at home (Astasari et al., 2019).

Supervision of the PPK program is under the responsibility of the principal. The principal constantly supervises and evaluates the head of the field and the coordinator of activities. Supervision of the principal on learning activities is in the classroom and Islamic living culture. This supervision aims to capture information and control over the implementation of PPK programs in schools.

\section{CONCLUSION}

School management integrated with the PPK program at SD Muhammadiyah Wibraga shows that schools can be an excellent place to educate generations of people of character. The process of PPK program management is internalized with character values able to achieve the expected goals to improve the quality of national education and give birth to a competent generation both from attitude, knowledge, and skills. 
The implementation of the PPK program at SD Muhammadiyah Wibraga provides many changes in a better direction. Those are the school's commitment to piloting PPK, sticking to the vision and mission that has been set, curriculum-based character education, and extracurricular PPK-based. Also, Islamic living culture, systemic-integrative management system, attitudes, and behaviors of intelligent and characterful students.

\section{REFERENCES}

Almuhajir, A. (2021). Controlling the Muhammadiyah Lhokseumawe Orphanage in Forming Independent Character of Foster Children. AlTanzim: Jurnal Manajemen Pendidikan Islam, 5(1), 176-189. https:/ / doi.org/10.33650/al-tanzim.v5i1.1962

Arif, D., \& Pratama, N. (2019). Tantangan Karakter Di Era Revolusi Industri dalam Membentuk Kepribadian Muslim. Al-Tanzim: Jurnal Manajemen Pendidikan Islam, 3(1), 198-226.

Silviani, S., Maarif, M. A., \& Wibowo, A. (2021). Knowledge Sharing Management: Strategy for Improving the Quality of Human Resources. Al-Tanzim: Jurnal Manajemen Pendidikan Islam, 5(1), 129-139.

Berkowitz, M. W., \& Bier, M. C. (2005). What Works in Character Education: A Research-Driven Guide for Educators. Washington DC: University of Missouri St Louis.

Darmayanti, S. E., \& Wibowo, U. B. (2014). Evaluasi Program Pendidikan Karakter di Sekolah Dasar Kabupaten Kulon Progo. Jurnal Prima Edukasia, 2(2), 223-234.

Rosyad, A. M., \& Zuchdi, D. (2018). Aktualisasi Pendidikan Karakter Berbasis Kultur Sekolah dalam Pembelajaran IPS di SMP. Harmoni Sosial: Jurnal Pendidikan IPS, 5(1), 79-92.

Dinas Kesehatan Provinasi DIY. (2016). Profil Kesehatan Daerah Istimewa Yogyakarta. Yogyakarta.

Hasbullah, H. M. (2015). Kebijakan Pendidikan (Perspektif Teori, Aplikasi, dan Kondisi Objektif Pendidikan di Indonesia). Jakarta: Rajawali Pers.

Kementerian Pendidikan dan Kebudayaan (Kemendikbud). (2017). Modul Pelatihan Penguatan Pendidikan Karakter bagi Guru. Jakarta.

Kemendikbud. (2016). Infografis Gerakan Penguatan Pendidikan Karakter. Jakarta.

Kemendikbud. (2011). Panduan Pelaksanaan Pendidikan Karakter, Kementerian Pendidikan Nasional. Jakarta.

Kontz, H., \& O'Donnel, C. (1990). Principles of Management: An Analysis of Management Function Harold Kontz dan Cyril O'Donnel (terj. Hutauruk). Jakarta: Erlangga.

Kurniawan, S. (2017). Pendidikan Karakter: Konsepsi \& Implementasinya secara Terpadu di Lingkungan Keluarga, Sekolah, Perguruan Tinggi, dan Masyarakat. Yogyakarta: Ar-Ruzz Media.

Lickona, T. (2013). Pendidikan Karakter: Panduan Lengkap Mendidikan Siswa Menjadi Pintar dan Baik. Bandung: Nusa Media. 
Maisaro, A., Wiyono, B. B., \& Arifin, I. (2018). Manajemen Program Penguatan Pendidikan Karakter di Sekolah Dasar. JAMP: Jurnal Administrasi dan Manajemen Pendidikan, 1(3), 302-312.

Maryam, S. (2018). Building Character Education Using Three Matra of Hasan Al-Banna'S Perspective in Pesantren. Jurnal Pendidikan Islam, 4(2), 51-62. https://doi.org/10.15575/jpi.v4i2.2422

Moleong, L. J. (2007). Metodologi Penelitian Kualitatif. Bandung: Remaja Rosdakarya.

Muhaimin. (2012). Pengembangan Kurikulum Pendidikan Agama Islam di Sekolah, Madrasah dan Perguruan Tinggi. Jakarta: Rajawali Press.

Mulyasa, E. (2012). Manajemen Pendidikan Karakter. Jakarta: Bumi Aksara.

Nasution, A. B., \& Siregar, R. H. (2013). Akhlak Tasawuf. Jakarta: Raja Grafindo Persada.

Qoyyimah, U. (2016). Inculcating character education through EFL teaching in Indonesian state schools. Pedagogies: An International Journal, 11(2), 109126.

Safitri, N. M. (2015). Implementasi pendidikan karakter melalui kultur sekolah di smp n 14 yogyakarta. Jurnal Pendidikan Karakter, 2(2), 173-183

Shihab, M. Q. (2016). Yang Hilang dari Kita: Akhlak. Tangerang: Lentera Hati.

Subiyantoro. (2013). Pengembangan Model Pendidikan Nilai Humanis-Religius Berbasis Kultur Madrasah. Cakrawala Pendidikan: Jurnal Ilmiah Pendidikan, 3(1), 326-340.

Sugiyono. (2013). Metode Penelitian Pendidikan: Pendekatan Kuantitatif, Kualitatif, dan $R \mathcal{E} D$. Bandung: Alfabeta.

Tilaar, H. A. R., \& Riant, N. (2009). Kebijakan Pendidikan: Pengantar untuk Memahami Kebijakan Pendidikan dan Kebijakan Pendidikan sebagai Kebijakan Publik. Yogyakarta: Pustaka Pelajar.

Wahid, A. H., Muali, C., \& Rafikah, K. (2018). Pengembangan Karakter Guru dalam Menghadapi Demoralisasi Siswa Perspektif Teori Dramaturgi. Jurnal Mudarrisuna, 8(1), 102-126.

Wiyani, N. A. (2012). Manajemen Pendidikan Karakter: Konsep dan Implementasinya di Sekolah. Yogyakarta: Pedagogia.

Wulandari, Y., \& Kristiawan, M. (2017). Strategi Sekolah dalam Penguatan Pendidikan Karakter Bagi Siswa dengan Memaksimalkan Peran Orang Tua. JMKSP (Jurnal Manajemen, Kepemimpinan, dan Supervisi Pendidikan), 2(2), 290-302.

Zamroni, Z. (2020). Smart Parenting in Improving Students' Spiritual Intelligence in Pesantren-Based Madrasahs. Ta'dib, 23(1), 51-62. https:// doi.org/10.31958/jt.v23i1.1947

Zulfaizah. (2018). Revitalisasi Pendidikan Agama dalam Pembentukan Karakter Peserta Didik di Madrasah. Elementary, 6(1), 43-62. 